Нуруллин Рафаиль Асгатович - доктор философских наук, профессор кафедры общей философии Института социально-философских наук Казанского (Приволжского) федерального университета. Адрес: 420008, Россия, г. Казань, ул. Кремлевская, А. 18. Тел.: +7 (843) 233-71-58. Эл. aspec: nurulla958@mail.ru

Nurullin Rafail Asgatovich, Doctor of Philosophy, Professor, Department of General Philosophy, Institute of Social and Philosophical Sciences, Kazan (Volga region) Federal University. Postal address: 18, Kremlyovskaya St, Kazan, Russian Federation, 420008. Tel.: +7 (843) 233-71-58. E-mail: nurulla958@mail.ru

DOI 10.17805/zpu.2018.4.27

\title{
Производственно-образовательный кластер как форма взаимодействия органов государственного управления и предпринимательских структур
}

\author{
Ю. Н. ЦАРЕГОРОДЦЕВ \\ МОСКОВСКИЙ ГУМАНИТАРНЫЙ УНИВЕРСИТЕТ
}

Аннотация учебника: Чиркин В. Е. Система государственного и муниципального управления : учебник. 5 изд., перераб. М. : Норма ; ИНФРА-М, 2018. 432 с.

Ключевые слова: государственное управление; муниципальное управление; региональная экономика; кадровый потенциал; человеческий капитал; производственно-образовательный кластер

$\mathrm{B}$ ышло в свет пятое издание учебника В. Е. Чиркина «Система государственного и муниципального управления» для студентов вузов, обучающихся по направлениям «Государственное и муниципальное управление», «Юриспруденция» (Чиркин, 2018). Содержание учебника включает 20 глав, в которых рассмотрены органы, управленческие структуры, особенности и взаимосвязи государственного и муниципального управления; организация государственной и муниципальной службы и роль должностных лиц государственного и муниципального управления. Также рассмотрены функции государственного управления в сфере экономики, социальных и других областях отношений; полномочия органов Российской Федерации, ее субъектов и муниципальных образований; возможности и своеобразие управленческих институтов, процедур и т. А. Вместе с тем представляется, что автор, исследуя результативность деятельности структур управления, недостаточно внимания уделяет оценке реализации или функций в области становления эффективной национальной инновационной системы.

Между тем одним из условий реализации сформулированной Президентом РФ стратегии научно-технологического прорыва является формирование инновационного партнерства государства, предпринимателей, научного и образовательного сообщества, населения. Ведущая роль в партнерстве должна принадлежать государству, которое может обеспечить ее реализацию через систему органов государственного и муниципального управления. Необходимость участия в инновационном партнер- 
стве предпринимателей, научно-образовательных организации и экономически активного населения определяется невозможностью изменения структуры воспроизводства без дальнейшего развития человеческого потенциала, отраслей, регионов, страны в целом.

В этих условиях конкурентные преимущества региональных экономик определяются способностью к ускоренному созданию и внедрению новейших технологий на основе интеграции предприятий и организаций, реализации кластерного подхода к профессиональному развитию трудовых ресурсов. Концептуальной основой кластера являются: принципы государственно-частного партнерства; требования к социально-экономическому развитию региона; положительные тенденции в системе образования, включая его регионализацию, непрерывность, вариативность, многоуровневость и т. д. Под производственно-образовательным региональным кластером понимается имеющая координирующий центр группа географически близких взаимосвязанных учебных заведений профессионального образования разного уровня, работодателей и органов государственного и муниципального управления, объединенных общей целью «интеллектуального производства».

Реализация концепции производственно-образовательного кластера предполагает преобразование системы подготовки кадров с целью приведения ее в соответствие с запросами регионального рынка труда, придания ей гибкости и адаптивности, возможности адекватно реагировать на текущие и перспективные потребности региона.

\section{СПИСОК АИТЕРАТУРЫ}

Чиркин, В. Е. (2018) Система государственного и муниципального управления : учебник. 5 изА., перераб. М. : Норма ; ИНФРА-М. 432 с.

Аата поступления: 10.10 .2018 г.

\section{PRODUCTION AND EDUCATIONAL CLUSTER AS A FORM OF INTERACTION BETWEEN PUBLIC ADMINISTRATION AND BUSINESSES \\ YU. N. TSAREGORODTSEV \\ MOSCOW UNIVERSITY FOR THE HUMANITIES}

A review of the textbook: Chirkin, V.E. (2018) Sistema gosudarstvennogo i munitsipalnogo upravleniia: uchebnik. 5 th ed. Moscow, Norma; INFRA-M. 432 p.

Keywords: public administration; municipal administration; regional economy; human resources; human capital; production and educational cluster

\section{REFERENCES}

Chirkin, V. E. (2018) Sistema gosudarstvennogo i munitsipal' nogo upravleniia: uchebnik. 5nd ed. Moscow, Norma; INFRA-M. 432 p. (In Russ.).

Submission date: $10 \cdot 10.2018$.

Царегородцев Юрий Николаевич - доктор экономических наук, профессор, заведующий кафедрой менеджмента Московского гуманитарного университета. Адрес: 111395, Россия, г. Москва, ул. Юности, д. 5. Тел.: +7 (499) 374-70-13. Эл. адрес: yutsaregorodtsev@mosgu.ru

Tsaregorodtsev Yuriy Nikolayevich, Doctor of Economics, Professor, Head, Department of Management. Moscow University for the Humanities. Postal address: 5, Yunosti St., Moscow, Russian Federation, 111395. Tel.: +7 (499) 374-70-13. E-mail: yutsaregorodtsev@mosgu.ru 